\title{
\begin{tabular}{l|l} 
Mitraries & DSpace@MIT
\end{tabular}
}

\author{
MIT Open Access Articles
}

\section{Partisan Gerrymandering and the Political Process: Effects on Roll-Call Voting and State Policies}

The MIT Faculty has made this article openly available. Please share how this access benefits you. Your story matters.

Citation: Caughey, Devin, Chris Tausanovitch, and Christopher Warshaw. "Partisan Gerrymandering and the Political Process: Effects on Roll-Call Voting and State Policies." Election Law Journal: Rules, Politics, and Policy 16, no. 4 (December 2017): 453-469. (C) 2017 Mary Ann Liebert, Inc.

As Published: http://dx.doi.org/10.1089/ELJ.2017.0452

Publisher: Mary Ann Liebert Inc

Persistent URL: http://hdl.handle.net/1721.1/119500

Version: Final published version: final published article, as it appeared in a journal, conference proceedings, or other formally published context

Terms of Use: Article is made available in accordance with the publisher's policy and may be subject to US copyright law. Please refer to the publisher's site for terms of use. 


\title{
Partisan Gerrymandering and the Political Process: Effects on Roll-Call Voting and State Policies
}

\author{
Devin Caughey, Chris Tausanovitch, and Christopher Warshaw
}

\begin{abstract}
Recent scholarship has documented the advantages of a new measure of partisan gerrymandering: the difference in the parties' wasted votes, divided by the total number of votes cast. This measure, known as the efficiency gap (EG), can be calculated directly from aggregate vote totals, facilitating comparison of the severity of party gerrymandering across states and time. In this article, we conduct the first analysis of the EG's effects on legislative representation and policymaking in the states. We first show that the partisan outcome of legislative elections has important causal effects on the ideological representation of individual districts, the ideological composition of legislative chambers, and the conservatism of state policymaking. We then show that variation in the EG across state-years is associated with systematic differences in the ideological location of the median state legislator and in the conservatism of state policies. These results suggest that partisan gerrymandering has major consequences not only for who wins elections but for the political process as a whole.
\end{abstract}

Keywords: redistricting, gerrymandering, state politics, representation, legislatures

\section{INTRODUCTION}

The mere fact that an apportionment scheme makes it more difficult for a particular group in a particular district to elect representatives of its choice does not render that scheme unconstitutional.... Rather, unconstitutional discrimination occurs only when the electoral system is arranged in a manner that will consistently degrade a voter's or a group of voters' influence on the political process as a whole.

-Davis v. Bandemer, 478 U.S. 109, 110 (1986)

[T] he First Amendment and the Equal Protection clause prohibit a redistricting scheme which (1) is

Devin Caughey is an associate professor in the Department of Political Science at the Massashusetts Institute of Technology (MIT) in Cambridge, Massachusetts. Chris Tausanovitch is an assistant professor in the Department of Political Science at the University of California, Los Angeles (UCLA) in Los Angeles, California. Christopher Warshaw is an assistant professor in the Department of Political Science at George Washington University in Washington, DC. intended to place a severe impediment on the effectiveness of the votes of individual citizens on the basis of their political affiliation, (2) has that effect, and (3) cannot be justified on other, legitimate legislative grounds.

—Whitford v. Gill, 218 F. Supp. 3d 837, 884

(W.D. Wis. Nov. 21, 2016)

G ERRYMANDERING HAS A LENGTHY, if not venerable, history in American politics. The term itself was coined in 1812 to mock a particularly serpentine legislative district drawn by Massachusetts Governor Elbridge Gerry and his fellow Democratic-Republicans. The purpose of that district, as with subsequent instances of partisan gerrymandering, was to distribute DemocraticRepublican voters more efficiently across districts than their opponents, thus increasing the number of seats occupied by Democratic-Republicans given the party's expected vote share (Cox and Katz 2002, xi). Though often lamented, partisan gerrymandering was long considered a "political question" beyond judicial remedy. This remained 
true even after the Supreme Court began in the 1960s to strike down redistricting schemes that created districts with unequal populations or that discriminated on the basis of race. The door to legal challenges opened a crack in 1986, when the Court ruled that partisan gerrymandering was in principle justiciable (Davis v. Bandemer, 478 U.S. 109 [1986]). Subsequent legal efforts to challenge actual instances of partisan gerrymandering, however, proved to be exercises in futility. In the 30 years following Davis v. Bandemer, despite many attempts, "not a single plaintiff ... managed to persuade a court to strike down a plan on this basis" (Stephanopoulos and McGhee 2015, 833). Only in 2016, when a three-judge panel invalidated Wisconsin's 2011 state assembly map on First Amendment and equal protection grounds, did a federal court first strike down an instance of partisan gerrymandering (Whitford v. Gill, 218 F. Supp. 3d 837 [W.D. Wis. Nov. 21, 2016]).

Notwithstanding this recent success, legal efforts to contest partisan gerrymandering have encountered a number of empirical challenges. One is devising a measure of partisan gerrymandering that courts find satisfactory. Traditionally, the scholarly literature has focused on two measures of partisan fairness: symmetry (in the vote-seat curves of different parties) and, to a lesser extent, responsiveness (of seat share to vote share). As McGhee (2014, 5660) observes, however, these traditional measures exhibit several shortcomings. Perhaps the most salient from a legal point of view is that they are counterfactual quantities that cannot be calculated from observed data alone but rather must be simulated under potentially strong assumptions. As an alternative, Stephanopoulos and $\mathrm{McGhee}$ (2015) have recently argued for measuring the severity of partisan gerrymandering using the efficiency gap (EG): the difference in the parties' wasted votes, divided by the total number of votes cast. Among other virtues, the EG can be calculated from observed vote returns even in contexts where one party wins a large majority of votes. Using this measure, Stephanopoulos and McGhee (2015) document a marked uptick in the absolute magnitude and proRepublican bias of partisan gerrymandering in recent elections. They also propose an EG of $7 \%$ as a judiciable threshold above which districting schemes would be deemed presumptively unconstitutional (cf. Jackman 2015, 56-69). In an indication of the measure's usefulness, an analysis of the EG was one of the grounds cited in Whitford v. Gill as evidence for the Wisconsin plan's unconstitutional discrimination against Democrats.

Although the development of the EG has improved the measurement of partisan gerrymandering, scholars still know relatively little about the EG's relationship with other quantities and outcomes of interest. In particular, it is unclear how the EG affects broader political dynamics. Understanding these effects is crucial, for the Supreme Court has made it clear that the "mere fact that an apportionment scheme makes it more difficult for a particular group in a particular district to elect representatives of its choice does not render that scheme unconstitutional." Rather, to violate equal protection the scheme must "consistently degrade a voter's or a group of voters' influence on the political process as a whole" (Davis v. Bandemer, 478 U.S. 109, 110 [1986]). In other words, the legal-not to mention normative-status of partisan gerrymandering hinges on how it affects not only the partisan scoreboard but also the substantive representation of ordinary citizens. ${ }^{1}$

This is the question that we take up in this article. Specifically, we examine how partisan gerrymandering of state legislative districts affects legislative representation and policymaking. We structure our empirical analysis in two parts. We first use an electoral regression-discontinuity (RD) design to estimate the effects of a party winning additional legislative seats, which is the overriding goal of partisan gerrymandering. Consistent with previous research, we show that all else equal, an extra legislative seat for a given party-especially if that seat determines majority control of a chamber-has massive effects on the conservatism of roll-call votes in state assemblies and more modest but still substantial effects on the conservatism of state policies (compare Shor and McCarty 2011; Caughey, Warshaw, and Xu, forthcoming). We then use a dynamic panel model to assess the effects of the efficiency gap itself on the same

\footnotetext{
${ }^{1}$ There has been little previous empirical work on how partisan gerrymandering affects substantive political outcomes. The existing works that are most closely related are those that consider potential trade-offs between descriptive and substantive representation raised by majority-minority districts (e.g., Cameron, Epstein, and O'Halloran 1996; Canon 1999; Lublin 1999). Yet these sorts of representational effects are crucial for evaluating the "effectiveness" of citizens' votes at influencing substantive policies that impact their everyday lives (Elmendorf 2017).
} 
outcomes. Again, we find that a pro-Republican EG shifts the median state legislator markedly to the right, whereas a pro-Democratic EG shifts the median to the left. Analogously, state policies become more conservative when the EG favors Republicans and (with less certainty) more liberal when the EG favors Democrats. Though smaller than its effects on legislative medians, the EG's policy effects are nonetheless substantial. Indeed, a one standard deviation change in the efficiency gap has a larger effect on state policy than a change in the party of the governor. Overall, these results suggest that partisan gerrymandering has major consequences not only for who wins elections but for the political process as a whole.

The remainder of the article is organized as follows. We begin with a brief theoretical overview of how partisan gerrymandering impacts the broader political process. We emphasize how the representational biases induced by partisan gerrymandering are magnified when parties are ideologically polarized. Second, we estimate the roll-call and policy effects of a party winning an extra seat, looking at three levels of analysis: individual districts, legislative chambers, and states as a whole. We then turn to a dynamic panel analysis of the efficiency gap itself, examining its effects on legislative medians and state policy conservatism. We also consider whether the effects of a proRepublican EG differ from those of a pro-Democratic one. Finally, we conclude with a discussion of partisan gerrymandering in the 2010 redistricting cycle, when the EG in a number of states reached levels rarely seen in previous decades. We illustrate with the example of Michigan, where a large efficiency gap transformed the state in a way that would have been very unlikely otherwise. We conclude that districting is only one factor that can impact state policy, but one that appears to be increasing markedly in importance.

\section{PARTISAN GERRYMANDERING AND THE POLITICAL PROCESS}

A key attribute of democracy, if not its very definition, is "responsiveness of the government to the preferences of its citizens, considered as political equals" (Dahl 1971, 1; May 1978). In modern large-scale democracies, citizens do not choose most government policies directly. Rather, they elect government officials, typically affiliated with one of several political parties, to represent them and formulate policies on their behalf (Pitkin 1967). Broadly speaking, there are two mechanisms by which elections can induce congruence with citizens' policy preferences: by incentivizing officials (through the threat of electoral reward and punishment) to pursue responsive policies, or by selecting officials whose policy preferences match those of the electorate (Fearon 1999). Under either mechanism, citizens' votes are a tool for influencing the policies implemented by the government. The relationship between the distribution of partisan support in the electorate and the partisan composition of the government-what Powell (2004) calls "vote-seat representation"-is thus a critical link in the longer representational chain between citizens' preferences and governments' policies. If the relationship between votes and seats systematically advantages one party over another, then some citizens will enjoy more influence-more "voice"-over government policies than others.

As a benchmark for understanding how partisan gerrymandering can distort representation, consider a hypothetical scenario in which legislators take the same policy positions as the median voter in their constituency. ${ }^{2}$ We can think of these policy positions as an "ideal point" on an ideological continuum. In such a scenario, we should expect candidates from different parties to differ little (if at all) within a given district but for the ideal points of officials of the same party to differ greatly depending on their district. Moreover, when we aggregate up to the state level, we should expect the median member in each legislative chamber to have the same ideal point as that of the median of district-specific median voters.

If the distribution of district-specific medians is asymmetric, then the ideal point of the median legislator will in general differ from that of the median voter in the state as a whole. For example, if a majority of districts lean slightly conservative but a large minority are solidly liberal — that is, if the distribution of district ideal points is skewed to the left - then the statewide median voter may be liberal even though the median of medians is slightly

\footnotetext{
${ }^{2}$ Such a scenario is most commonly motivated by a model of a two-party system with electorally motivated candidates incentivized to converge on the median voter (Downs 1957), but it can also arise in models of policy-motivated candidates where selection is voters' only mechanism for inducing responsiveness (Besley and Coate 1997). In presuming the existence of a unique median voter, we are implicitly assuming that political positions vary along a single left-right dimension.
} 
conservative. Moreover, because the support of the median legislator is a necessary if not sufficient condition for the passage of new legislation, discrepancies between the median voter and the median district will likely be reflected in policymaking as well. Thus, even under ideal conditions where individual legislators perfectly represent the median voter in their district, "an asymmetric distribution of districtlevel ideal points can bring systematic bias ... in the transformation of preferences to policies" (Rodden 2010, 328).

In the scenario just described, partisanship per se plays no role. This is because candidates from different parties all converge on the median voter in a bid to win the competition for votes. As abundant research has shown, however, the theoretical prediction of median convergence is not borne out by the empirical realities of contemporary American politics. Rather, due to the pull of their partisan subconstituencies, the constraints imposed by national party brands, and other factors, the campaign platforms and legislative behavior of Democrats and Republicans representing the same constituency diverge substantially from each other and from the constituency's median voter (Poole and Rosenthal 1984; Ansolabehere, Snyder, and Stewart 2001; Lee, Moretti, and Butler 2004; Shor and McCarty 2011; Fowler and Hall 2017; for theoretical perspectives, see Snyder and Ting 2003; Grofman 2004). Because relatively conservative districts are also more likely to elect Republicans, intradistrict divergence between Democratic and Republican officeholders magnifies the ideological effects of asymmetrically distributed districts. For example, if the median voter is slightly liberal but the median district is slightly conservative (and thus leans Republican), the median legislator is likely to be a Republican who is more conservative not only than the median voter statewide but also than the median voter in their own district. Thus, even if partisan control of the legislature has no additional effect beyond determining the ideological location of the median legislator (Krehbiel 1993), partisan polarization exacerbates the policymaking bias of partisan gerrymandering, skewing policy outcomes even farther from the median voter.

In sum, partisan gerrymandering does not merely make it easier for one party to win elections. Rather, by biasing the relationship between votes and seats, it also undermines congruence with voters' preferences, skewing the ideological composition of the legislature and the ideological character of policymaking away from the preferences of the median voter (and thus from a majority of the electorate). This is true even if Democratic and Republican candidates in the same district adopt exactly the same policy positions. The effect is magnified, however, if the parties are ideologically polarized, as they are in the contemporary United States. Partisan gerrymandering thus undermines the political influence of a majority of citizens relative to the supporters of the advantaged party, biasing the political process as a whole.

\section{THE EFFECTS OF AN EXTRA SEAT IN THE LEGISLATURE}

When one party has an advantage in the districting process, this increases the probability of that party's candidates winning election to the legislature. In this section, we examine the effects that the partisan outcome of legislative elections has on the political process more generally. How much does electing a Republican rather than a Democrat actually affect the ideological composition of the legislature and, ultimately, the policies promulgated by state governments? We consider this question at three levels. First, at the level of the individual district, we estimate the causal effect of Republican victory on the roll-call voting of the district's representative. Second, at the level of the legislative chamber, we estimate the effect of a Republican floor majority on the conservatism of the median legislator. Third, at the level of the state, we estimate the effect of a Republican legislative majority on the conservatism of state policies. With these answers in hand, we will turn in the next section to the question of how the efficiency gap itself affects the political process.

To estimate the effects of electing Republicans rather than Democrats, we take advantage of a powerful statistical tool: an electoral regressiondiscontinuity design (Lee 2008). The intuition behind an electoral RD design is that under certain oftenplausible assumptions, the outcomes of very close elections can be considered approximately random. Consequently, elections that a Republican barely lost can be considered ex ante identical on average to elections that a Republican barely won. That is, a valid RD design ensures that the outcomes of the closest elections are independent of all pre-election attributes, observable and unobservable. Any postelection differences between districts barely won and lost by Republicans (e.g., the roll-call record of 
the elected representative) can thus be attributed to the causal effect of the election outcome and not, say, to the preexisting conservatism of the district's electorate. In practice, the estimation of RD effects entails modeling the relationship between vote share and the outcome variable separately for elections Republicans won and lost and comparing how the relationship "jumps" at the 50\% threshold separating Republican victories and defeats. ${ }^{3}$

\section{Effect on conservatism of individual legislators}

As noted above, we begin by estimating the effect of Republican electoral victory on how an individual district is represented in the legislature. Although an individual state legislator may cast hundreds or even thousands of roll-call votes, their voting behavior can usually be parsimoniously summarized in terms of a single left-right score, their estimated ideal point (Shor and McCarty 2011; compare Poole and Rosenthal 1997). Using roll-call records from all 50 state legislatures, Shor and McCarty (2011) have estimated the ideal points of the members of every state legislature in each session between 1995 and $2014 .^{4}$ These estimated ideal points summarize the ideological differences between different legislators, as expressed in their roll-call votes for and against legislative proposals. In addition, Klarner et al. (2013) have gathered data on state legislative elections between 1967 and 2012.

Figure 1 illustrates the RD estimate of the effect of Republican victory on legislative roll-call behavior. Each gray dot in the figure represents a single election to the lower house of a state legislature. The horizontal axis indicates the Republican margin in that election, and the vertical axis indicates the winning candidate's estimated ideal point in the subsequent session (normalized to have a standard deviation of 1 across legislators). The hollow circles indicate the average ideal point in $0.5 \%$ bins, and the regression lines are a linear approximation of the relationship between Republican margin and legislator conservatism. As indicated by the difference between the two regression lines at the $0 \%$ threshold, electing a Republican rather than a Democratic state legislator causes roll-call conservatism to increase by about 1.3 standard deviations on average over the 1995-2012 period. It should be emphasized that the RD design implicitly holds constant districts' Republican vote share as well as all other pre-election attributes. This analysis there- fore isolates the causal effect of an additional Republican seat, separate from other determinants of legislators' voting behavior. Note that the withinparty relationship between vote share and conservatism is almost flat, indicating that narrowly elected legislators take similar positions to those elected by 10 percentage points or more. This suggests that what matters most for legislators' roll-call votes is not the margin by which one party wins but merely the identity of the winning party.

\section{Effect on conservatism of legislative medians}

We now consider the effects of the partisan outcome of elections on a legislative chamber as a whole. Our analysis presumes that election outcomes are the most consequential when they determine the majority party in the chamber. Apart from any other benefits to controlling the chamber (see Cox, Kousser, and McCubbins 2010; Anzia and Jackman 2012), majority status is likely to have large effects on the ideological location of the median voter in the legislature, at least if there is little ideological overlap between the parties (as is the case in the contemporary Congress). Since new legislation cannot pass without the median's support, the ideological location of the median has outsized influence over the policymaking process.

Majority control of a legislative chamber is a function of not one but many elections. Thus, to estimate the effect of majority control we employ a

\footnotetext{
${ }^{3}$ The validity of the regression-discontinuity (RD) design hinges on the assumption that only the winning candidate - and not the distribution of units' potential outcomes - changes discontinuously at the threshold (Hahn, Todd, and Klaauw 2001). Unlike U.S. House elections, where incumbents appear to have an advantage in very close elections (Caughey and Sekhon 2011), our analysis of state legislative and gubernatorial elections uncovers no statistically significant pre-treatment discontinuities. Following Calonico, Cattaneo, and Titiunik (2014a, 2014b), we estimate both pre- and post-treatment discontinuities with local linear regression, using a bandwidth chosen to minimize meansquare-error (MSE) and adjusting confidence intervals to account for bias in the local-linear estimator.

${ }^{4}$ Shor and McCarty (2011) also use data from the National Political Awareness Test, a survey of legislators run by Project Vote Smart, in order to make comparisons between legislators across different states. Each legislator is assigned a score. These scores bear some resemblance to ratings that are given to legislators by interest groups. However, the scores are based on all roll-call votes. In addition, they are assigned by a measurement model that takes advantage of the similarities between the coalitions that emerge on different votes, rather than by subjective judgements of the individual votes. Specifically, they use a two-parameter item response model.
} 


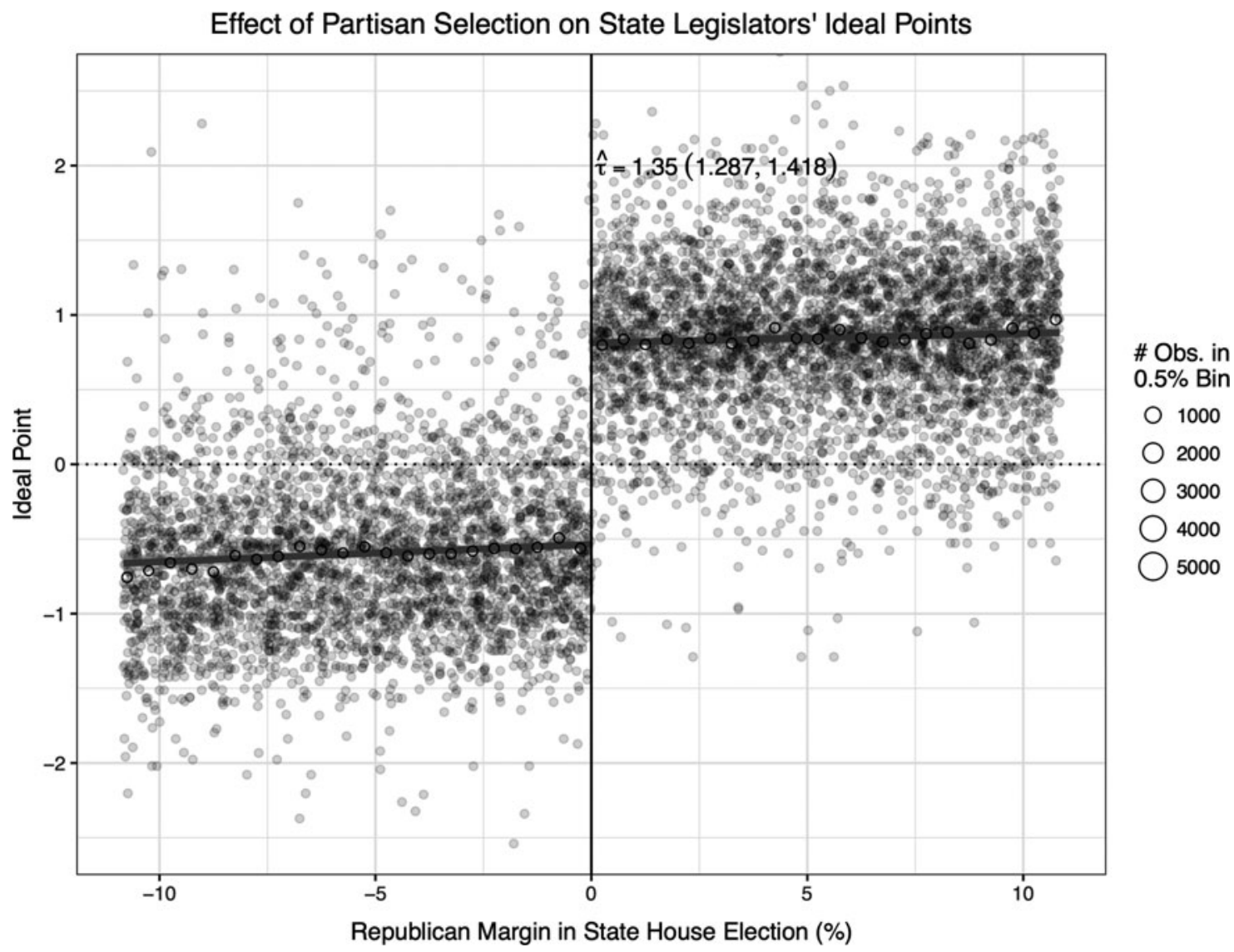

FIG. 1. The effect of partisan selection on state legislators' ideal points, 1995-2012.

modified version of the basic RD design called a multidimensional regression-discontinuity (MRD) design (Feigenbaum, Fouirnaies, and Hall, forthcoming), which combines information from multiple close elections. ${ }^{5}$ Figure 2 illustrates the effect of majority control on conservatism of the median voter in legislative lower houses, again using the ideal points estimated by Shor and McCarty (2011). ${ }^{6}$ According to the MRD analysis, bare Republican control of a legislative chamber increases the conservatism of the median legislator by $0.74-a$ bit over half the ideological effect of Republican victory at the district level. As a point of comparison, the standard deviation (SD) of legislative medians in these data is 0.68 . As before, this estimate is based on states that are comparable in all respects except that close legislative races happened to break towards Republican candidates in one set of states and towards the Democrats in another. As such, it isolates the ideological benefit to conservatives that accrues from an extra Republican seat that flips legislative control.

\section{Effect on conservatism of state policies}

Finally, we evaluate how the partisan outcome of elections affects what is arguably the ultimate metric of representation: government policies. For a number of reasons, we should expect the partisan outcome of elections-even elections that

\footnotetext{
${ }^{5}$ The assignment variable Feigenbaum, Fouirnaies, and Hall (forthcoming) suggest is the Euclidean distance between a vector of district-level electoral results and the electoral results required for majority status. The first step in constructing this variable is to determine the number of seats $(m)$ short of majority status the minority party is after a given election. Then, obtain the Euclidean distance from majority status by summing the squares of the margins in the minority party's $m$ closest losses in that election and taking the square root. Multiply this measure by -1 if the Republicans are in the minority. For example, if the Republicans are $m=2$ seats short of a majority and the margins in their two closest losses are respectively $3 \%$ and $4 \%$, then the value of the assignment variable is $-1 \times \sqrt{3^{2}+4^{2}}=-5$.

${ }^{6}$ Since multi-member house districts cause complications for the design, state-years with multi-member districts are dropped from the analysis. We also drop Nebraska, which has a nonpartisan legislature.
} 


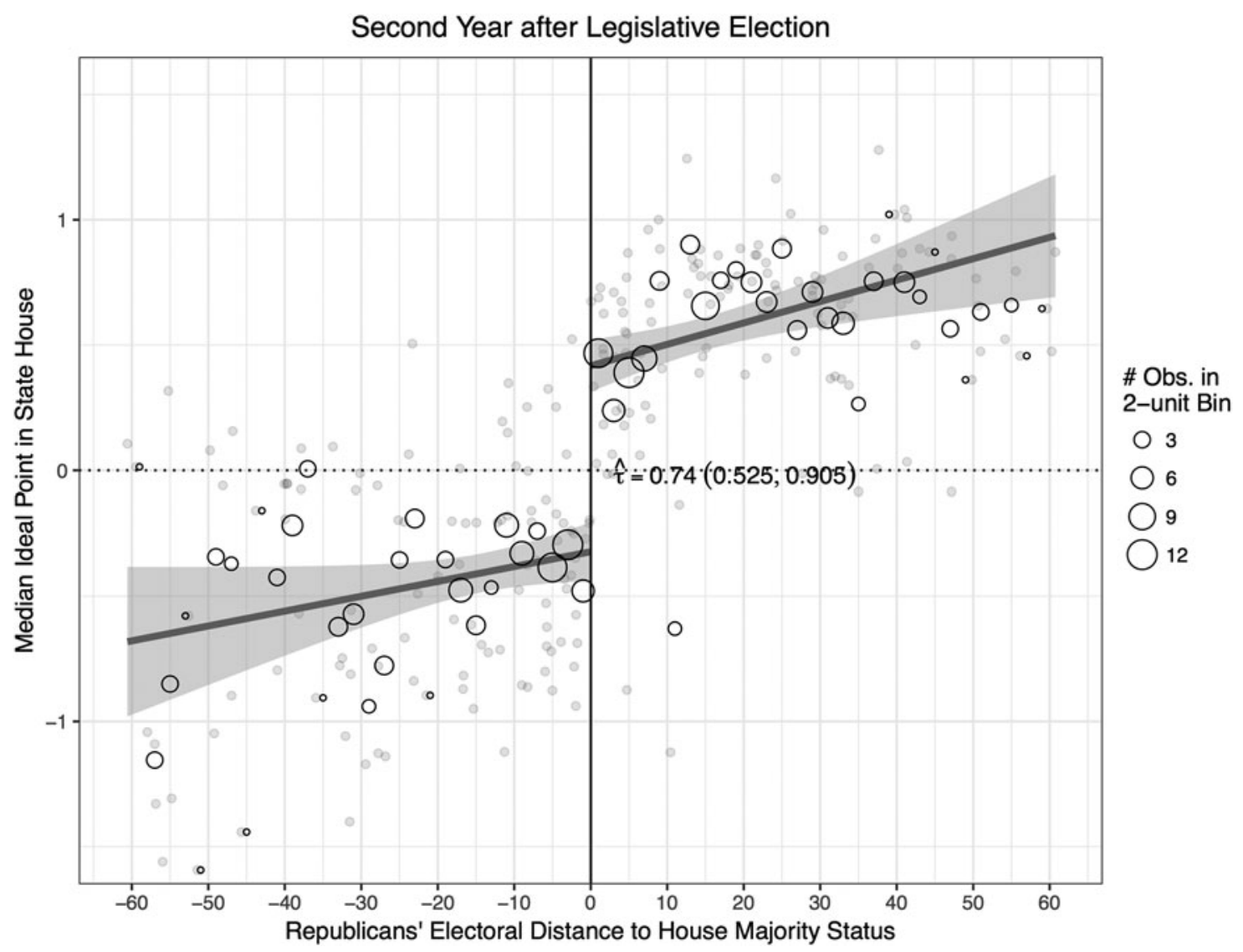

FIG. 2. Party effects on legislative medians.

determine the majority party-to have a more muted effect on policy outcomes than it does on ideal points. Existing policies are often difficult to overturn, not least because new laws require majorities in both legislative chambers (or supermajorities, if vetoed by the governor). These and other limitations to majority rule often force the majority party to compromise with the minority (e.g., Alesina, Londregan, and Rosenthal 1993; Anzia and Jackman 2012). States also face a variety of policymaking constraints, such as resource limitations and "race-to-the-bottom" competition with other states. Even if policy effects are small, however, achieving these effects is the putative goal of partisan competition.

To estimate the effect of majority party control on government policies, we again rely on an MRD design. In doing so, we closely parallel the analysis in Caughey, Warshaw, and Xu (forthcoming), who investigated the same question for elections between 1968 and 2012. Like them, we summarize the ideological content of state policies using the annual measure of state policy liberalism developed by Caughey and Warshaw (2016), which is based on a total of nearly 150 individual policies. ${ }^{7}$ The dataset underlying these scores is designed to include all

${ }^{7}$ The Caughey-Warshaw measure is derived from a model of the relationship between states' latent policy liberalism and the probability of adopting a particular policy. The scores are permitted to change smoothly over time for each state. In more technical terms, it is a dynamic Bayesian factor-analytic model for mixed data. The model, which extends that of Quinn (2004), is dynamic in that policy liberalism is estimated separately in each year and the policy-specific intercepts (or "difficulties") are allowed to drift over time. If, instead, the intercepts are held constant, the policies of all states are estimated to have become substantially more liberal, especially before the 1980s. Each policy's factor loading (or "discrimination"), which captures how "ideological" the policy is, is held constant over time. This allows benchmarks for what is a liberal or conservative policy to change over time as conditions on the ground change. For instance, both technologies and social conditions have evolved substantially over time. As a result, it would not be appropriate to say that a particular state is more liberal in 2012 because it built solar power plants that were not possible to build in 1968 . 


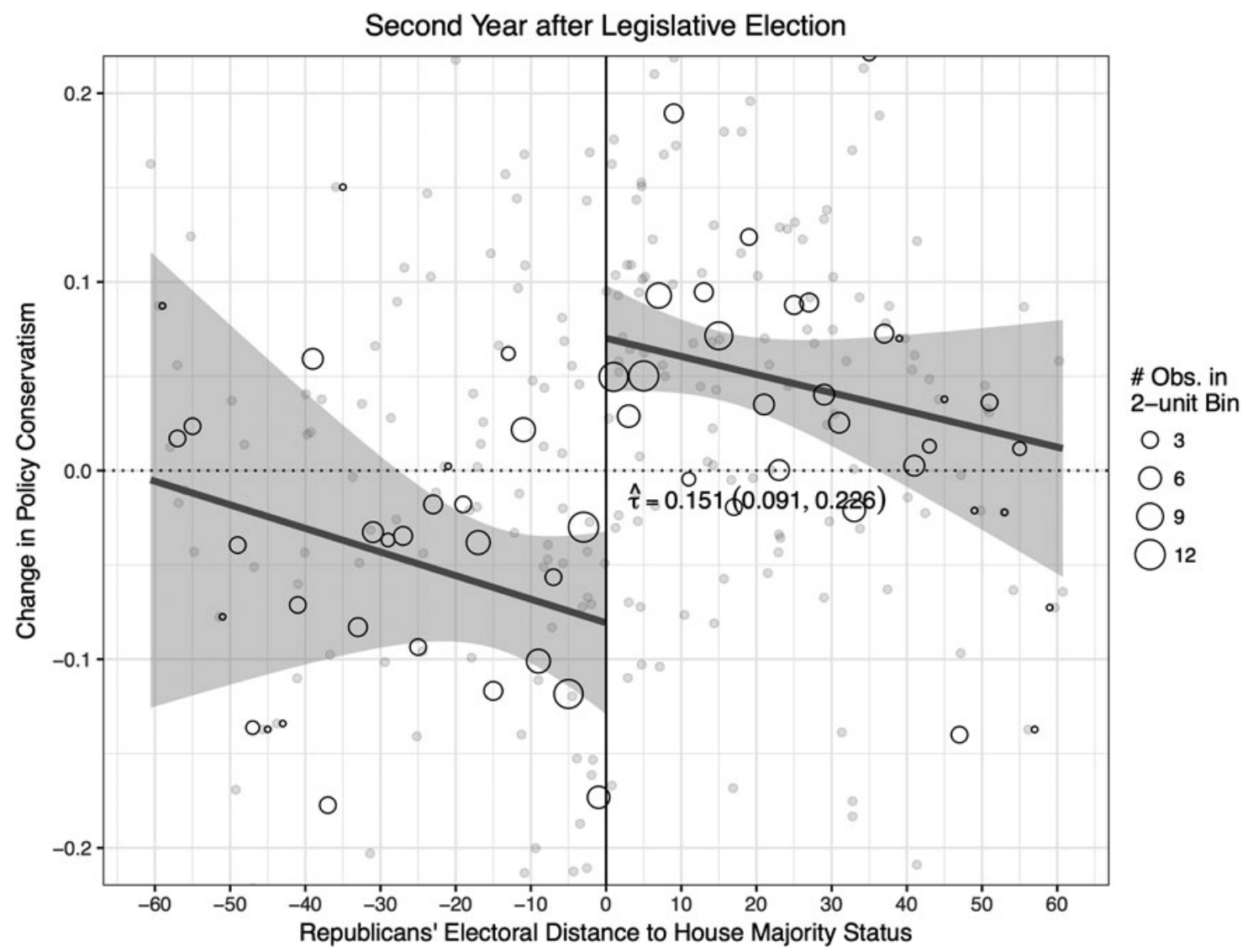

FIG. 3. Party effects on policy.

politically salient state policy outputs on which comparable data are available for at least five years. ${ }^{8}$ The data cover a wide range of policy areas, including social welfare (e.g., Aid to Families with Dependent Children/Temporary Assistance for Needy Families [AFDC/TANF] benefit levels), taxation, labor (e.g., right-to-work), civil rights (e.g., fair housing laws), women's rights (e.g., jury service for women), morals legislation (e.g., anti-sodomy laws), family planning (e.g., ban on partial-birth abortion), the environment (e.g., state endangered species acts), religion (e.g., public schools allowed to post Ten Commandments), criminal justice (e.g., death penalty), and drugs (e.g., marijuana decriminalization). Despite the diversity of policies, Caughey and Warshaw (2016) find evidence that only a single score (dimension) is adequate to explain the policy variation across states and correlates highly with domain-specific indices of policy liberalism.

Figure 3 plots the MRD estimate of the effect of a Republican majority in the lower house on change in the conservatism of state policies (that is, reverse- coded policy liberalism). ${ }^{9}$ This analysis is identical to that of Caughey, Warshaw, and $\mathrm{Xu}$ (forthcoming), except that we consider only the the period 1995 to 2012 and also measure policy conservatism two years after the election instead of one. Our more recent time period makes a difference, though. Our estimated effect of 0.15 standard deviations is almost three times larger than the average effect over the entire 1968-2012 period. This is consistent with Caughey, Warshaw, and Xu's conclusion that the effects of partisan control have grown markedly in recent decades.

To summarize the results so far, we have estimated the ideological effects of the partisan outcome of elections at three levels: the district, the

\footnotetext{
${ }^{8}$ Unlike many studies, the dataset explicitly excludes social outcomes (e.g., infant-mortality rates) as well as more fundamental government institutions (e.g., legislative term limits).

${ }^{9}$ We estimate the effect on change rather than levels because doing so greatly increases statistical power.
} 
legislative chamber, and the state. We found that, all else equal, electing a Republican rather than a Democrat makes a district's representation in the legislature more than a standard deviation more conservative (see Figure 1). Similarly, electing a bare Republican majority in a legislative chamber also increases the conservatism of the chamber median by about a standard deviation (see Figure 2). Consistent with the many sources of status quo bias in policymaking, the effect of partisan legislative majorities on state policies is more muted but still substantial. Over the course of each two-year term, a narrow Republican majority in the state house can be expected to increase state policy conservatism by 0.15 SDs, whereas a narrow Democratic majority can be expected to decrease policy conservatism by about the same amount (see Figure 3). In short, each additional Republican seatespecially if it determines the majority party-has significant effects not only on legislators' roll-call behavior but also on the kinds of policies a state implements.

\section{THE EFFECTS OF THE EFFICIENCY GAP}

So far, we have shown that whether a Democrat or a Republican wins election in a given district has very large effects on the ideological representation that district receives in the state legislature. If the seat in question has an impact on majority control, the partisan outcome of elections also has large effects on the conservatism of the median legislator in the chamber and more modest but still robust effects on the conservatism of state policies. Crucially, these are the effects of seat share in itself, holding constant the parties' relative popularity and all other pre-election attributes. Overall, these findings imply that a party can reap substantial ideological and policy benefits if it can increase the number of seats it wins at a given level of electoral support.

The goal of partisan gerrymandering is to create legislative districts that are as "efficient" as possible in translating a party's vote share into seat share. In practice, this entails drawing districts in which the supporters of the advantaged party constitute either a slim majority or a small minority. The former is achieved by "cracking" local opposingparty majorities across multiple districts and the latter by "packing" them into a few overwhelming strongholds. Both types of districts "waste" more votes of the disadvantaged party than of the advantaged one. The disadvantaged party either narrowly loses, wasting a large number of votes without winning a seat, or wins overwhelmingly, wasting a large number of votes above the $50 \%+1$ needed to win. The resulting asymmetry in the efficiency of the vote-seat relationships of the two parties lies at the core of normative and constitutional critiques of partisan gerrymandering.

A simple yet powerful way to operationalize this concept of partisan gerrymandering is the efficiency gap, which is defined as "the difference between the parties' respective wasted votes, divided by the total number of votes cast in the election" (Stephanopoulos and McGhee 2015, 831; see also McGhee 2014). If districts are equal in turnout the EG can be calculated from statewide election results using the formula

$$
E G=S-.5-2(V-.5)
$$

where $S$ is the major-party proportion of legislative seats won by the focal party (in our case, Republicans) and $V$ is the two-party proportion of statewide votes won by that party. As this formula makes clear, when vote share is evenly divided the EG boils down to the size of the Republican majority in the legislature (i.e., the proportion Republican minus 0.5). But a key advantage of the EG over other measures of partisan bias is that it can be calculated directly from observed election returns even when the parties' vote shares are not equal. In either case, the EG measures the extra seats one party wins over and above what would be expected if neither party were advantaged in the translation of votes to seats (i.e., if they had the same number of wasted votes).

Based on the findings reported in the previous section, we should expect the extra seats controlled by a party as a result of the efficiency gap to affect both the ideological composition of the state legislature and the ideological orientation of state policies. That is, we should expect a positive EG (indicating pro-Republican bias) to increase the conservatism of state legislatures and policies, and vice versa for a negative (pro-Democratic) EG. To test this hypothesis, we estimate the effect of the EG on the two statewide outcomes examined in the previous section: the ideal point of the median state house member and the conservatism of the 
state's policies. We do so using a dynamic panel model (DPM), which exploits within-state variation in the EG across elections (Beck and Katz 2011). Specifically, our DPM estimates the dynamic relationship between each outcome and the EG controlling for the outcome's value in previous years, state- and year-specific intercepts, and two timevarying characteristics of the state: the party of the governor and the Republican vote share in the last presidential election. ${ }^{10}$ Intuitively, this specification can be interpreted as comparing different years within the same state and estimating the difference in the yearly change in state conservatism depending on whether the EG is relatively high or relatively low for that state. Though it doesn't account for alternative explanations as effectively as the RD design used in the previous section, our model does help rule out the possibility that EG's apparent effect is confounded by states' recent electoral or policy history or by unobserved factors specific to a given state or year.

We estimate the EG's effect on state legislative medians and policy conservatism in a dataset covering all but nine U.S. states between 1972 and 2014. Our data on the EG in each state-year are taken from Jackman (2015). ${ }^{11}$ We use Shor and McCarty's (2011) estimates of state legislative medians and Caughey and Warshaw's (2016) measure of state policy conservatism. The final dataset consists of data on 786 elections across 41 states.

Before we turn to our analyses, we should emphasize that we are not estimating the effect of partisan gerrymandering per se. The EG can be non-zero and differ across states for reasons unrelated to the drawing of district lines, such as variation in how different demographic groups are distributed across space (Chen and Rodden 2013). The EG can also be affected by the intentional drawing of district lines to accomplish goals other than maximizing partisan seat share, such as ensuring the representation of racial minorities (e.g., Brace, Grofman, and Handley 1987). Intentional partisan gerrymandering, however, can result in districts that far exceed natural variation in the EG. Chen (forthcoming), for example, uses a series of computer simulations to demonstrate that Wisconsin's 2012 plan was very unlikely to be entirely caused by geography. Indeed, the plan "exhibits a Republican-favoring efficiency gap several times that of most simulated plans, and over twice as large as even the most biased of the 200 plans pro- duced by the non-partisan computer simulation process." The analyses that follow thus indicate the potential political gains to one party if it succeeds in manipulating district lines to its own advantage.

\section{The efficiency gap and the median legislator}

We know that partisan advantages in the efficiency gap give one party a larger seat share than they would have received without any advantage in the efficiency gap. We also know that electing a Republican rather than a Democrat leads to more conservative roll-call positions (Figure 1). Putting these facts together leads to the clear expectation that changes in the efficiency gap should lead to changes in the position of the median voter in state legislatures. But the magnitude of changes in the position of the median voter is not clear a priori. This depends on whether additional members of the majority party tend to be moderate (because they are winning close districts) or typical for their party (when parties are polarized). As the seat share of the majority party grows, the median voter will be closer to the center of the majority party. At the same time, the center itself may be moving depending on the positions of the new members.

Table 1 shows the effect of the efficiency gap on the median ideal point of state legislators in lower chambers (Shor and McCarty 2011). The first column shows the results of a model that include fixed effects (FEs) for state as well as year. These specifications capture the relationship between the efficiency gap and legislative roll-call voting patterns within states net of national trends, eliminating the influence of time-invariant state-specific confounders. It also includes a lagged outcome variable to control for states' recent policy history. The estimates indicate that state-years in which the efficiency gap was more pro-Republican than average for that state also tended to have more conservative

$$
\begin{aligned}
& { }^{10} \text { Formally, we use the following specification: } \\
& \qquad y_{s t}=\delta E G_{s, t-1}+\sum_{l=1}^{L} \rho_{l} y_{s, t-l}+\alpha_{s}+\xi_{t}+\beta \mathbf{X}_{s t}+\varepsilon_{s t},
\end{aligned}
$$

where $y_{s t}$ is the state $s$ 's outcome in year $t, E G_{s, t-1}$ is $s$ 's efficiency gap one year before $t, y_{s, t-1}$ is $s$ 's outcome $l$ years before $t, \alpha_{s}$ and $\xi_{t}$ are state- and year-specific intercepts, and $\mathrm{X}_{s t}$ is a matrix of time-varying state covariates.

${ }^{11}$ Many state legislative races are uncontested. For these races, Jackman (2015) imputes the Democratic share of the vote based on presidential election results and other state legislative results in a given district. 
Table 1. The Effect of the Efficiency Gap on the Median Ideology in State Lower Chambers

\begin{tabular}{|c|c|c|c|c|}
\hline & \multicolumn{4}{|c|}{ Dependent variable: } \\
\hline & \multicolumn{4}{|c|}{ Median ideal point in state house } \\
\hline & (1) & (2) & (3) & (4) \\
\hline Efficiency gap $_{t-1}$ & $\begin{array}{c}0.043 * * * \\
(0.005)\end{array}$ & $\begin{array}{c}0.042 * * * \\
(0.005)\end{array}$ & & \\
\hline Efficiency gap (pro-Republican) $)_{t-1}$ & & & $\begin{array}{c}0.234 * * * \\
(0.067)\end{array}$ & $\begin{array}{c}0.242 * * * \\
(0.065)\end{array}$ \\
\hline Efficiency gap (pro-Democratic) $)_{t-1}$ & & & $\begin{array}{r}-0.198 * * \\
(0.088)\end{array}$ & $\begin{array}{r}-0.163 * \\
(0.084)\end{array}$ \\
\hline Republican presidential share & & $\begin{array}{c}0.034 * * * \\
(0.007)\end{array}$ & & $\begin{array}{c}0.036 * * * \\
(0.008)\end{array}$ \\
\hline 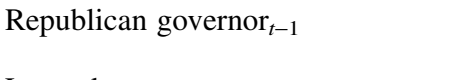 & $\begin{array}{l}-0.040 \\
\quad(0.042)\end{array}$ & $\begin{aligned}-0.062 & (0.040)\end{aligned}$ & $\begin{array}{r}-0.035 \\
\quad(0.046)\end{array}$ & $\begin{array}{r}-0.058 \\
(0.045)\end{array}$ \\
\hline Lagged outcome & $\begin{array}{c}0.353 * * * \\
(0.056)\end{array}$ & $\begin{array}{c}0.289 * * * \\
(0.055)\end{array}$ & $\begin{array}{c}0.485 * * * \\
(0.058)\end{array}$ & $\begin{array}{c}0.411^{* * *} \\
(0.058)\end{array}$ \\
\hline Year FEs & $\mathrm{X}$ & $\mathrm{X}$ & $\mathrm{X}$ & $\mathrm{X}$ \\
\hline State FEs & $\mathrm{X}$ & $\mathrm{X}$ & $\mathrm{X}$ & $\mathrm{X}$ \\
\hline Lagged outcome variable & $\mathrm{X}$ & $\mathrm{X}$ & $\mathrm{X}$ & $\mathrm{X}$ \\
\hline Observations & 321 & 321 & 321 & 321 \\
\hline$R^{2}$ & 0.858 & 0.870 & 0.830 & 0.844 \\
\hline Adjusted $R^{2}$ & 0.826 & 0.840 & 0.791 & 0.807 \\
\hline
\end{tabular}

Note: $* p<0.1 ; * * p<0.05 ; * * * p<0.01$.

FE, fixed effects.

roll-call voting behavior in the state house. A one percentage point pro-Republican shift in the efficiency gap moves the median ideal point in the state house 0.043 standard deviations to the right. These estimates suggest, for example, that the median ideal point of the Wisconsin state house, which had a 0.13 pro-Republican efficiency gap in 2012 , would shift nearly 0.6 standard deviations to the left if it adopted a districting plan with no efficiency advantage for either party.

In column (2), we add the Republican presidential vote in the previous presidential election. This controls for variation in the position of the median voter in the state. Not surprisingly, we find that states that are more Republican in presidential elections also have a more conservative state house. The effect of the efficiency gap, however, is essentially identical here to the model in column (2).

So far, we have assumed a linear relationship between the efficiency gap and legislative roll-call voting patterns. In columns (3) and (4), we relax this assumption to examine how efficiency gaps outside the threshold of 0.07 suggested by Jackman (2015) influence the median ideal point. ${ }^{12}$ Here, we find that a pro-Republican efficiency gap of more than 0.07 shifts the median ideal point in the state house 0.23 standard deviations to the right, while a pro-Democratic efficiency gap shifts the median ideal point 0.20 standard deviations to the left. The results are essentially identical in column (4) when we control for presidential vote share.

We further relax the linearity assumption between the efficiency gap and legislative roll-call voting patterns in Figure 4. Here, we graph the non-parametric relationship between residualized efficiency gaps and the median ideal point in the state house. ${ }^{13}$ Once again, the graph shows the large and significant relationship between the efficiency gap and roll-call behavior. Interestingly, it suggests that pro-Republican efficiency gaps have a larger effect on state legislative behavior than pro-Democratic efficiency gaps. Indeed, a proRepublican efficiency gap of 0.075 is associated with a shift to the right in the median ideal point of 0.375 standard deviations to the right, while a similar pro-Democratic efficiency gap is associated with a shift of the median ideal point 0.25 standard

\footnotetext{
${ }^{12}$ Based on all districting plans since 1972, Jackman argues that an efficiency gap of 0.07 is a reasonable threshold because efficiency gaps larger than 0.07 tend to be durable, usually lasting an entire redistricting period. Moreover, efficiency gaps larger than this are relatively uncommon, reducing the burden on the courts.

${ }^{13}$ We residualize both the efficiency gap and the median ideal point using a model similar to the one in column (1) of Table 1, with two-way fixed effects and lagged ideal points.
} 


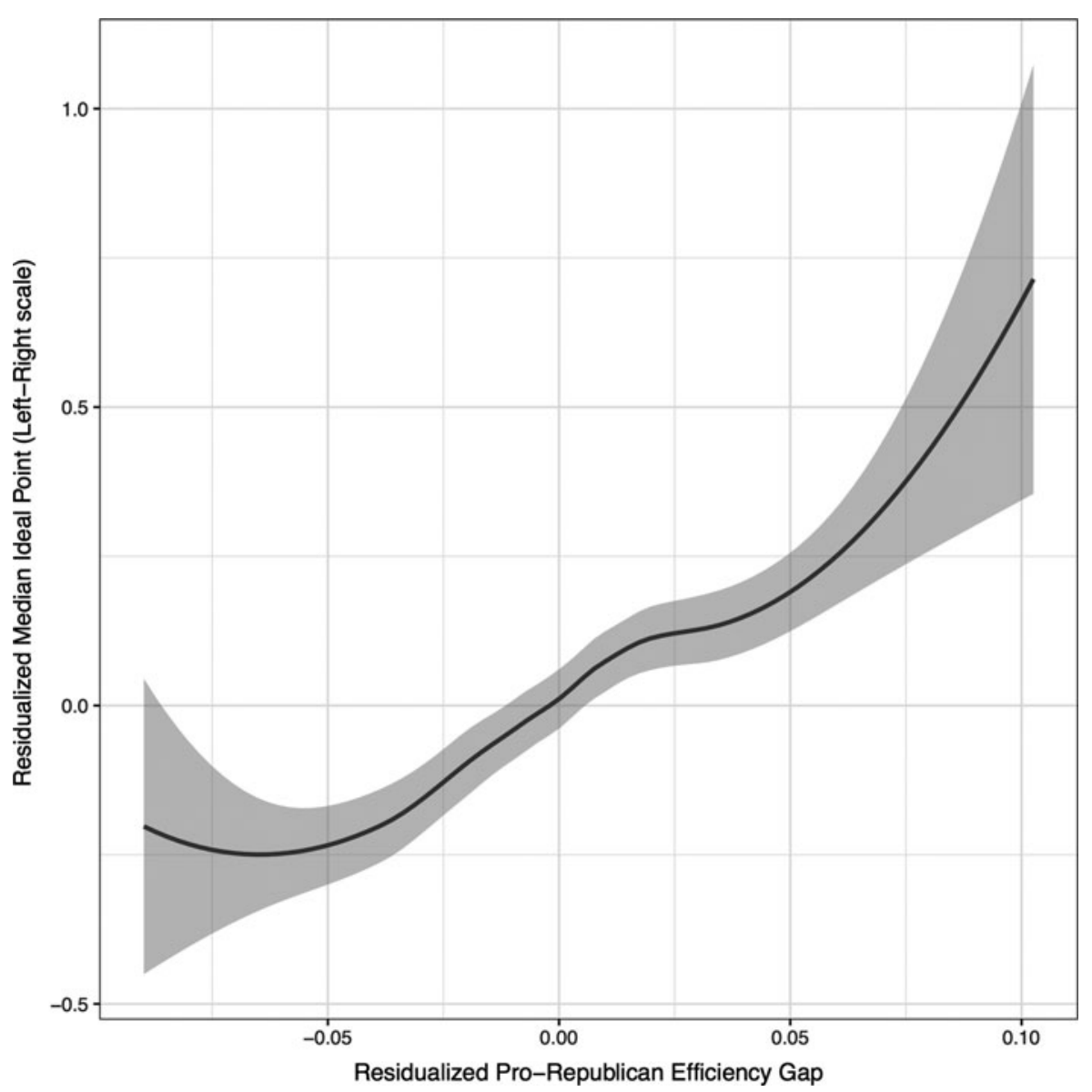

FIG. 4. Relationship between efficiency gap and median ideal point in state house.

deviations to the left. It thus appears to be the case that marginal Democratic members have been more likely to reflect the views of moderate voters, whereas marginal Republican members have been more likely to reflect their party.

\section{The efficiency gap and state policy conservatism}

Next, we examine the effect of the efficiency gap on state policy conservatism. Previous research shows that the partisan composition of state legislatures has an important effect on policy (Caughey, Warshaw, and $\mathrm{Xu}$, forthcoming). Table 2 reports the results of dynamic panel specifications analogous to those in Table 1. It indicates that a one percentage point pro-Republican shift in the efficiency gap increases state policy conservatism by 0.004 standard deviations. This means that a seven percentage point increase in the efficiency gap would increase policy conservatism by 0.028 standard deviations, which is equivalent to about a half-percentage point increase in the percentage of conservative policies in a state. This effect is similar to the effect of a shift of one percentage point in the composition of the vote for president (column 2) and is larger than the effect of a governor's partisanship.

Of course, this analysis assumes a linear relationship between the efficiency gap and state policy. In column (3), we relax this assumption to examine how efficiency gaps outside the threshold of 0.07 suggested by Jackman (2015) influence state policy conservatism relative to a baseline efficiency gap between -0.07 and 0.07 . Here, we find that a pro-Republican efficiency gap of more than 0.07 increases state policy conservatism 0.05 standard deviations, while a pro-Democratic efficiency gap decreases state policy conservatism 0.03 standard deviations. This analysis provides additional evidence that pro-Republican efficiency gaps have had a larger effect on state policy than pro-Democratic efficiency gaps.

We further relax the linearity assumption between the efficiency gap and state policy conservatism in 
Table 2. The Effect of the Efficiency Gap on State Policy Conservatism

\begin{tabular}{|c|c|c|c|c|}
\hline & \multicolumn{4}{|c|}{$\begin{array}{l}\text { Dependent variable: } \\
\text { State policy conservatism }\end{array}$} \\
\hline & (1) & (2) & (3) & (4) \\
\hline Efficiency gap $_{t-1}$ & $\begin{array}{c}0.004 * * * \\
(0.001)\end{array}$ & $\begin{array}{c}0.004 * * * \\
(0.001)\end{array}$ & & \\
\hline Efficiency gap (pro-Republican) $)_{t-1}$ & & & $\begin{array}{c}0.049 * * * \\
(0.013)\end{array}$ & $\begin{array}{c}0.052 * * * \\
(0.013)\end{array}$ \\
\hline Efficiency gap (pro-Democratic) $)_{t-1}$ & & & $\begin{array}{r}-0.030 * * \\
(0.014)\end{array}$ & $\begin{array}{r}-0.022 \\
\quad(0.014)\end{array}$ \\
\hline Republican governor $_{t-1}$ & $\begin{array}{l}0.013 \\
(0.008)\end{array}$ & $\begin{array}{l}0.015^{*} \\
(0.008)\end{array}$ & $\begin{array}{l}0.012 \\
(0.008)\end{array}$ & $\begin{array}{l}0.015^{*} \\
(0.008)\end{array}$ \\
\hline Lagged outcome & $\begin{array}{c}0.936^{* * * *} \\
(0.015)\end{array}$ & $\begin{array}{c}0.913 * * * \\
(0.016)\end{array}$ & $\begin{array}{c}0.933 * * * \\
(0.015)\end{array}$ & $\begin{array}{c}0.909 * * * \\
(0.016)\end{array}$ \\
\hline Republican presidential share & & $\begin{array}{c}0.004 * * * \\
(0.001)\end{array}$ & & $\begin{array}{c}0.004 * * * \\
(0.001)\end{array}$ \\
\hline Year FEs & $\mathrm{X}$ & $\mathrm{X}$ & $\mathrm{X}$ & $\mathrm{X}$ \\
\hline State FEs & $X$ & $X$ & $X$ & $X$ \\
\hline Lagged outcome variable & $\mathrm{X}$ & $\mathrm{X}$ & $\mathrm{X}$ & $\mathrm{X}$ \\
\hline Observations & 748 & 748 & 748 & 748 \\
\hline$R^{2}$ & 0.992 & 0.992 & 0.992 & 0.992 \\
\hline Adjusted $R^{2}$ & 0.991 & 0.991 & 0.991 & 0.991 \\
\hline
\end{tabular}

Note: ${ }^{*} p<0.1 ; * * p<0.05 ; * * * p<0.01$.

Figure 5. Here, we graph the non-parametric relationship between residualized efficiency gaps and state policy conservatism. ${ }^{14}$ This figure shows a large and significant relationship between the efficiency gap and state policy. Again, it indicates that pro-Republican efficiency gaps have a somewhat larger effect on policy than pro-Democratic efficiency gaps. Indeed, a pro-Democratic efficiency gap of 0.1 is associated with a shift to the left in policy of 0.04 standard deviations, while a proRepublican efficiency gap leads to a shift to the right of 0.05 standard deviations. In addition, larger pro-Republican efficiency gaps have even larger effects on state policy, while pro-Democratic efficiency gaps never increase state policy conservatism more than 0.04 standard deviations. In short, the efficiency gap has important effects on both legislative representation and state policymaking, and these effects appear to be larger when the EG favors Republicans than when it favors Democrats.

\section{CONCLUSION}

In this article, we have examined the effect of the party of a representative on roll-call voting and state policy. We find that an efficiency gap in the districting process affects the state legislature and the me- dian ideology of members of the state legislature. Perhaps more importantly, we find that the efficiency gap has a significant effect on state policy. Overall, our findings suggest that partisan bias in the legislative districting process has an important effect on elections, legislative behavior, and representation. Thus, limiting the magnitude of partisan biases in the efficiency gap is likely to improve state governments' representation of their citizens.

A critique of this article might point out that policy change at the state level tends to happen gradually, even in cases with skewed districting, with rare exceptions. This happens for a variety of reasons. The differences between the parties at the state levels have often been small compared to the difference at the national level, with a fair amount of deference to the political culture of the state (Erikson, Wright, and McIver 1993). Governors can be idiosyncratic, forging unique political brands that do not match preconceived notions of their political party. Moreover, because there are multiple branches of government and bicameral legislatures in all states but Nebraska, checks and balances

\footnotetext{
${ }^{14}$ We residualize both the efficiency gap and state policy conservatism using a model similar to the one in column (1) of Table 2, with two-way fixed effects and lagged policy conservatism.
} 


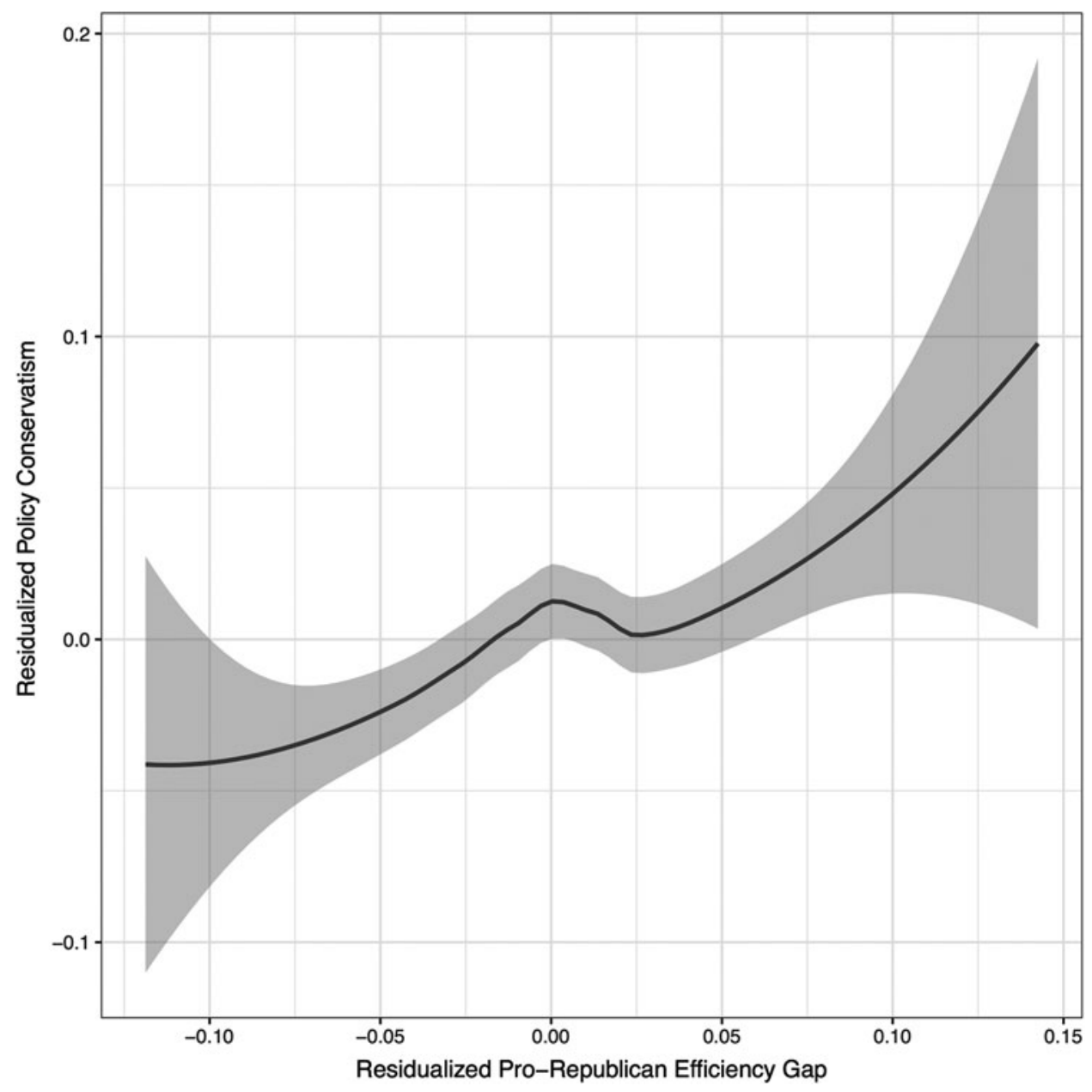

FIG. 5. Relationship between efficiency gap and state policy conservatism.

can slow policy change down. When the composition of one chamber of the state legislature changes, the other may not follow immediately, or there may be an opposition governor. Once one-party government takes hold, some changes may be made quickly, but after that the focus often shifts to holding off the other party, sometimes for decades. Change is slow in the making.

But there are also reasons to believe that large swings in policy may be becoming more common and that districting will be an important contributor to this trend. Polarization is spreading from the national level to the states. As a result, party control of state governments is more consequential. Moreover, the ability to draw districts has the potential to contribute to this trend. In the year 2000 districting cycle, personal computing was still in its infancy, and the ability to use computer algorithms to optimize maps was extremely limited. By 2010 this had changed dramatically. Computer software run- ning on a laptop had the ability to draw thousands of maps, optimized to a range of criteria including partisan advantage. This is probably one reason why efficiency gaps in the 2010 s are some of the largest on record. A mitigating factor is the rise of non-partisan redistricting commissions, which have the potential to reduce partisan biases in the districting process.

Districting in the 2010 cycle was dominated by Republicans largely due to their success in the previous cycle of state-level elections. In 2010, Republicans controlled 25 state legislatures to the Democrats' 16 . The average pro-Republican efficiency gap in 2012 was 0.04 . In fact, in six states the efficiency gap resulted in a situation where a majority of voters supported Democrats in the state assembly in 2012 or 2014, but the majority of the assembly was Republican. These states provide straightforward demonstrations of why changes in districts do not always correspond to 
big policy changes. At the same time, they show how big counter-majoritarian policies can arise as a direct result of districting and why we might expect this situation to become more common if the status quo approach to districting prevails.

Of the six states that achieved a Democratic vote majority but a Republican seat majority in either 2012 or 2014, five of them had Republican control of the state legislature and the governorship prior to the election. This was the case in Florida, Michigan, Ohio, Pennsylvania, and Wisconsin. As a result, to the extent that each state pursued ambitious conservative policies, many of these had already been achieved. Minnesota had a Democratic governor who could veto conservative changes. These six states did not see big swings in a conservative direction as a direct result of their Republican majorities in these years. However, this is not to say that policy was not affected by the mismatch between voters and legislators. It's quite possible that Minnesota would have moved policy to the left had the legislature been controlled by Democrats. In the other four states, Republican governors would have had to make greater compromises with Democrats in the legislature.

Despite the fact that big programmatic changes in policy did not result after 2012 and 2014, a closer look at Michigan shows what can happen when there are severe mismatches between voters and legislators. In the 2011-2012 session, Michigan advanced an ambitious conservative agenda that included a large spending cut, higher taxes on pensions, and lower taxes on corporations. While the nation was swiftly trending to the left on gay rights, Michigan placed a ban on benefits for same-sex partners of public employees. Perhaps most significantly, in December 2012 Michigan became a rightto-work state, forbidding contracts that require workers to pay union dues. This was a grievous blow for unions in a state that has historically been a stronghold for organized labor.

All of this occurred despite the fact that in 2010, Democrats received a bare majority of the votes for the Michigan state assembly, $50.4 \%$. Despite this performance, Republicans received $57.3 \%$ of the seats, for an efficiency gap of 0.08 . This allowed Republicans to pass the right-to-work law without a single Democratic vote and despite a few defections from their own membership. As social scientists, we are cautious about making strong statements about counterfactuals, particularly about a single case. But in this instance, it seems very unlikely that Governor Rick Snyder's conservative agenda would have gone forward if the efficiency gap had been 0. If this had been the case, then Democrats would have had a majority in the state assembly. It is very doubtful that a Democratic legislator would have been willing to cross the aisle to undermine the unions, a key constituency for the Democratic party.

Given Republican control of the state legislature during the 2010 redistricting cycle, it is not surprising that the efficiency gap has gotten substantially larger in Michigan, with gaps of 0.14 in 2012 and 0.13 in 2014. In both years, Democrats received majorities of the state assembly votes but minorities of the seats. Republican state legislatures have solidified the governor's transformation of the state. While it so happens in this case that the most salient legislative achievements came before the new districts were instituted, this case demonstrates the substantial impact that a large efficiency gap can have when the circumstances are right. The key ingredients were very polarized legislative parties and a sympathetic governor. Even if the Democrats win back the governorship, it will be very hard for them to win back the state assembly given the districts that have been drawn.

Of course, Democrats too have benefited from efficiency gaps in their favor, especially in years before the Republican-dominated 2010 redistricting cycle. Just as in Michigan, these pro-Democratic EGs biased policymaking towards the advantaged party. In Vermont, for example, a EG of -0.07 helped Democrats win $51 \%$ of lower-house seats in the 1998 elections. ${ }^{15}$ In the ensuing term, the state house narrowly approved a controversial bill providing for same-sex civil unions, which ultimately became the first such law in the nation (Goldberg 2000). The popular backlash against the law contributed to Republicans' capture of the state house in the 2000 elections, but Democrats' continued hold on the governorship and state senate prevented the law from being repealed.

The case of Vermont again illustrates how a large efficiency gap, especially if it determines which party controls the legislature, can lead to large

\footnotetext{
${ }^{15}$ Of the 150 seats in the Vermont House of Representatives, 77 (51\%) were held by Democrats, 67 (45\%) by Republicans, and the remaining 6 by independents and members of minor parties.
} 
policy changes that are difficult to reverse. Thus, even if large policy effects are rare, they can lead to durable policy biases relative to public opinion. More commonly, efficiency gaps can deny the majority of voters the opportunity to reverse past policies that they dislike or to enact large policy changes themselves. In short, efficiency gaps can degrade the disfavored party's influence on the political process, both in the short term and over the longer term as well.

\section{REFERENCES}

Alesina, Alberto, John Londregan, and Howard Rosenthal. 1993. "A Model of the Political Economy of the United States.” American Political Science Review 87(1): 12-33.

Ansolabehere, Stephen, James M. Snyder, Jr., and Charles Stewart, III. 2001. "Candidate Positioning in U.S. House Elections." American Journal of Political Science 45(1): 136-159.

Anzia, Sarah F. and Molly C. Jackman. 2012. "Legislative Organization and the Second Face of Power: Evidence from US State Legislatures." Journal of Politics 75(1): 210-224.

Beck, Nathaniel and Jonathan N. Katz. 2011. "Modeling Dynamics in Time-Series-Cross-Section Political Economy Data." Annual Review of Political Science 14:331352.

Besley, Timothy and Stephen Coate. 1997. "An Economic Model of Representative Democracy." Quarterly Journal of Economics 112(1): 85-114.

Brace, Kimball, Bernard Grofman, and Lisa Handley. 1987. "Does Redistricting Aimed to Help Blacks Necessarily Help Republicans?” Journal of Politics 49(1): 169-185.

Calonico, Sebastian, Matias D. Cattaneo, and Rocío Titiunik. 2014a. rdrobust: Robust Data-Driven Statistical Inference in Regression-Discontinuity Designs. $\mathrm{R}$ package version 0.70. <http://CRAN.R-project.org/package=rdrobust $>$.

2014b. "Robust Nonparametric Confidence Intervals for Regression-Discontinuity Designs.” Econometrica 82(6): 2295-2326.

Cameron, Charles, David Epstein, and Sharyn O'Halloran. 1996. "Do Majority-Minority Districts Maximize Substantive Black Representation in Congress?" American Political Science Review 90(4): 794-812.

Canon, David T. 1999. Race, Redistricting, and Representation: The Unintended Consequences of Black Majority Districts. Chicago: University of Chicago Press.

Caughey, Devin and Jasjeet S. Sekhon. 2011. "Elections and the Regression Discontinuity Design: Lessons from Close U.S. House Races, 1942-2008." Political Analysis 19(4): 385-408.

Caughey, Devin, and Christopher Warshaw. 2016. "The Dynamics of State Policy Liberalism, 1936-2014." American Journal of Political Science 60(4): 899-913.

Caughey, Devin, Christopher Warshaw, and Yiqing Xu. Forthcoming. "Incremental Democracy: The Policy Effects of
Partisan Control of State Government." Journal of Politics 79(4).

Chen, Jowei. Forthcoming. "Analysis of Computer-Simulated Districting Maps for the Wisconsin State Assembly." Election Law Journal.

Chen, Jowei and Jonathan Rodden. 2013. "Unintentional Gerrymandering: Political Geography and Electoral Bias in Legislatures." Quarterly Journal of Political Science 8(3): 239-269.

Cox, Gary W. and Jonathan N. Katz. 2002. Elbridge Gerry's Salamander: The Electoral Consequences of the Reapportionment Revolution. New York: Cambridge University Press.

Cox, Gary W., Thad Kousser, and Mathew D. McCubbins. 2010. "Party Power or Preferences? Quasi-Experimental Evidence from American State Legislatures." Journal of Politics 72(3): 799-811.

Dahl, Robert A. 1971. Polyarchy: Participation and Opposition. New Haven, CT: Yale University Press.

Downs, Anthony. 1957. An Economic Theory of Democracy. New York: Harper/Row.

Elmendorf, Christopher S. 2017. "From Educational Adequacy to Representational Adequacy: A New Template for Legal Attacks on Partisan Gerrymanders." Unpublished manuscript. https://ssrn.com/abstract=2916294.

Erikson, Robert S., Gerald C. Wright, and John P. McIver. 1993. Statehouse Democracy: Public Opinion and Policy in the American States. Cambridge University Press.

Fearon, James D. 1999. "Electoral Accountability and the Control of Politicians: Selecting Good Types versus Sanctioning Poor Performance." In Democracy, Accountability, and Representation, edited by Adam Przeworski, Susan Carol Stokes, and Bernard Manin. New York: Cambridge University Press.

Feigenbaum, James J., Alexander Fouirnaies, and Andrew B. Hall. Forthcoming. "The Majority Party Disadvantage: Revising Theories of Legislative Organization." Quarterly Journal of Political Science. <https://dl.dropboxusercontent .com/u/11481940/FFH_majority_disadvantage.pdf $>$.

Fowler, Anthony and Andrew Hall. 2017. "Long Term Consequences of Elections." British Journal of Political Science 47(2): 351-372.

Goldberg, Carey. 2000. "Vermont's House Backs Wide Rights for Gay Couples." New York Times. March 17. <https:// nyti.ms/2s9yiGE>.

Grofman, Bernard. 2004. "Downs and Two-Party Convergence." Annual Review of Political Science 7:25-46.

Hahn, Jinyong, Petra Todd, and Wilbert Klaauw. 2001. "Identification and Estimation of Treatment Effects with a Regression-Discontinuity Design." Econometrica 69(1): 201-209.

Jackman, Simon. 2015. "Assessing the Current Wisconsin State Legislative Districting Plan.” Unpublished expert report. Whitford v. Gill, W.D. Wis.

Klarner, Carl, William Berry, Thomas Carsey, Malcolm Jewell, Richard Niemi, Lynda Powell, and James Snyder. 2013. State Legislative Election Returns (1967-2010). ICPSR34297-v1. Ann Arbor, MI: Inter-university Consortium for Political and Social Research [distributor], 201301-11. doi:10.3886/ICPSR34297.v1. 
Krehbiel, Keith. 1993. "Where's the Party?" British Journal of Political Science 23(2): 235-266.

Lee, David S. 2008. "Randomized Experiments from NonRandom Selection in US House Elections." Journal of Econometrics 142(2): 675-697.

Lee, David S., Enrico Moretti, and Matthew J. Butler. 2004. "Do Voters Affect or Elect Policies? Evidence from the U. S. House." Quarterly Journal of Economics 119(3): 807-859.

Lublin, David. 1999. "Racial Redistricting and AfricanAmerican Representation: A Critique of 'Do MajorityMinority Districts Maximize Substantive Black Representation in Congress?'” American Political Science Review 93(1): 183-186.

May, John D. 1978. "Defining Democracy: A Bid for Coherence and Consensus." Political Studies 26(1): 1-14.

McGhee, Eric. 2014. "Measuring Partisan Bias in SingleMember District Electoral Systems." Legislative Studies Quarterly 39(1): 55-85.

Pitkin, Hanna Fenichel. 1967. The Concept of Representation. Berkeley: University of California Press.

Poole, Keith T. and Howard Rosenthal. 1984. "The Polarization of American Politics.” Journal of Politics 46(4): 1061-1079. . 1997. Congress: A Political-Economic History of Roll Call Voting. New York: Oxford UP.

Powell, G. Bingham, Jr. 2004. "Political Representation in Comparative Politics." Annual Review of Political Science 7:273-296.
Quinn, Kevin M. 2004. "Bayesian Factor Analysis for Mixed Ordinal and Continuous Responses." Political Analysis 12(4): 338-353.

Rodden, Jonathan. 2010. "The Geographic Distribution of Political Preferences.” Annual Review of Political Science 13(1): 321-340.

Shor, Boris and Nolan McCarty. 2011. "The Ideological Mapping of American Legislatures." American Political Science Review 105(3): 530-551.

Snyder, James M., Jr. and Michael M. Ting. 2003. "Roll Calls, Party Labels, and Elections." Political Analysis 11(4): 419-444.

Stephanopoulos, Nicholas O. and Eric M. McGhee. 2015. "Partisan Gerrymandering and the Efficiency Gap." University of Chicago Law Review 82(2): 831-900.

Address correspondence to: Christopher Warshaw Department of Political Science George Washington University 2115 G Street, N.W. Monroe Hall 440 Washington, DC 20052

E-mail:warshaw@gwu.edu 